\title{
The delay appearance of Cambrian explosion linked to marine $\mathrm{N}_{2} \mathrm{O}$ production
}

\author{
ZHENFEI WANG ${ }^{1}$, KANGJUN HUANG ${ }^{1}$
}

${ }^{1}$ Shaanxi Key Laboratory of Early Life and Environment, State Key Laboratory of Continental Dynamics, and Department of Geology, Northwest University, Xi'an 710069, China

The Ediacaran-Cambrian (E-C) transition is a critical period that witnessed the Earth's first extraordinary radiations and extinctions of complex multicellular life. The latest Ediacaran fauna that may represent the earliest phase of the Cambrian Explosion, disappeared $\sim 20$ million years before the subsequent Cambrian radiation. The trigger mechanism for the disappearance of the Ediacaran biota and the delay appearance of Cambrian explosion are poorly understood.

To explore the possible driving force for early animal evolution during the $\mathrm{E}-\mathrm{C}$ transition, we measured nitrogen isotope $\left(\delta^{15} \mathrm{~N}\right)$, pyrite sulfur isotope $\left(\delta^{34} \mathrm{~S}_{\mathrm{py}}\right)$, organic carbon isotope $\left(\delta^{13} \mathrm{C}_{\mathrm{org}}\right)$ compositions of the late Ediacaran to Cambrian Stage 3 strata spanning from platform facies to slope-basin facies of the Yangtze Block. Our data show that coupled negative excursion of $\delta^{15} \mathrm{~N}, \delta^{34} \mathrm{~S}_{\mathrm{py}}$ and $\delta^{13} \mathrm{C}_{\mathrm{org}}$ occurred during the E-C transition, suggesting elevated denitrification and microbial sulfate reduction (MSR) rate, which dramatically enhanced nitrous oxide $\left(\mathrm{N}_{2} \mathrm{O}\right)$ discharge due to extremely low $\mathrm{Cu}$ concentration in the sulfide ocean. Nitrous oxide, a powerful greenhouse gas that drives global warming, which then accounts for lower dissolved oxygen in seawater, more sluggish thermohaline circulation and weakened ocean ventilation. The expansion of euxinic area lead by eustasy rise have resulted in Ediacaran macroscopic animal extinctions. However, continuous consume $\mathrm{NO}_{3}{ }^{-}$and $\mathrm{NO}_{2}{ }^{-}$in seawater by denitrification would limit denitrification rate and reduce $\mathrm{N}_{2} \mathrm{O}$ production. As such, nitrogen fixation became the main source of biologically available nitrogen for primary producers accompanying with the global climate cooling in Stage 3. While positive shifts in $\delta^{13} \mathrm{C}_{\text {org }}$ and $\delta^{34} S_{\mathrm{py}}$ suggest the increased deposition rates and the improved primary productivity, which would be caused by enhanced upwelling and sea level decline. However, a trend to lighter $\mathrm{N}$ isotopes followed by an increase to heaver $\delta^{15} \mathrm{~N}$ in platform facies appear to be associated with an increased availability of aerobic nitrogen cycling. Our observations suggest nitrous oxide played an important driving force in shaping the structures of biosphere and establishing metazoan-dominated ecosystems. 